\title{
THE VICISSITUDES OF HERBALISM IN LATE NINETEENTH- AND EARLY TWENTIETH-CENTURY BRITAIN
}

by

\section{P. S. BROWN*}

In the middle of the nineteenth century, there was fierce confrontation between British herbalists, under the influence of Thomsonian medical botany, and the orthodox medical profession which was then in the throes of ordering its own ranks. ${ }^{1}$ Towards the end of the century, this excitement had diminished and herbalists became less conspicuous, but a small group continued to struggle to improve their professional status. Then, early in the twentieth century, these herbalists suffered a series of reverses, mainly because of legislation which in their terms granted monopoly to the orthodox profession.

Despite all difficulties, herbalists persisted; and patients continued to consult them. Currently, their persistence seems to have been rewarded, and it is suggested by writers such as Griggs, Stuart, and Inglis ${ }^{2}$ that there is now a major reawakening of public interest in herbalism. This results partly from the toxic medications of the orthodox practitioner and his neglect of the patient as a person, but largely from social change which has produced a new type of patient seeking herbal therapy. Corresponding shifts of attitude in herbalism can be detected earlier in the century.

This paper is concerned with the tradition and the change in herbalism from the final quarter of the nineteenth century until the early years of the Second World War and publication of the Beveridge Report. This is a natural point at which to pause because the National Health Service after the war introduced a new phase in the history of herbalism. The number and diversity of the herbalists will be discussed, with an attempt to identify the beliefs and practices which defined them as a distinct group. This is necessary because the meaning of the term "herbalist" is not selfevident, the regular practitioners being enthusiastic prescribers of medicines derived from plants. The herbalists' struggle to achieve professional status and to dispel out-dated stereotypes will then be considered, attention being focused on the

*P. S. Brown, BA, BM, MRCP, 65 Northover Road, Westbury-on-Trym, Bristol BS9 3LQ

${ }^{1} \mathrm{P}$. S. Brown, 'Herbalists and medical botanists in mid-nineteenth-century Britain with special reference to Bristol', Med.Hist., 1982, 26: 405-420.

${ }^{2}$ Barbara Griggs, Green pharmacy, London, Norman \& Hobhouse, 1981, pp. 327-336. M. Stuart, 'The fall and rise of medical herbalism', Herbal Review, 1976, 1: 4-6; and in M.Stuart (editor), The encyclopaedia of herbs and herbalism, London, Orbis, 1979, p.11. B.Inglis, Natural medicine, Glasgow, Collins, 1979. 
turbulent 1930s when, it is suggested, a basis was laid for the present phase of herbalism.

\section{HOW MANY HERBALISTS?}

Trade lists from directories for the contrasting districts of Bristol and South Wales have been used to estimate and follow the changes in numbers of herbalists and medical botanists between 1871 and 1939 (Figs. 1 and 2) ${ }^{3}$ The striking differences in these regions illustrate the importance of local social and economic factors. The dramatic rise of herbalists recorded in South Wales between 1871 and 1921 must reflect the increase in industrialization which occurred there and in the adjacent Monmouthshire valleys. ${ }^{4}$ South Wales became more like the industrial North, and a report in 1910 claimed that the herbalist's practice was "especially noticeable in Lancashire, the West Riding of Yorkshire, Nottinghamshire and Derbyshire . . . and

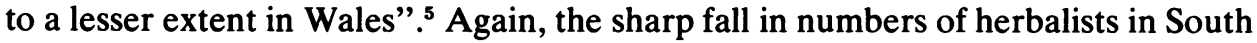
Wales in the 1920s and 30s, compared with Bristol, must reflect the severity and duration of slump and depression in that region. ${ }^{6}$
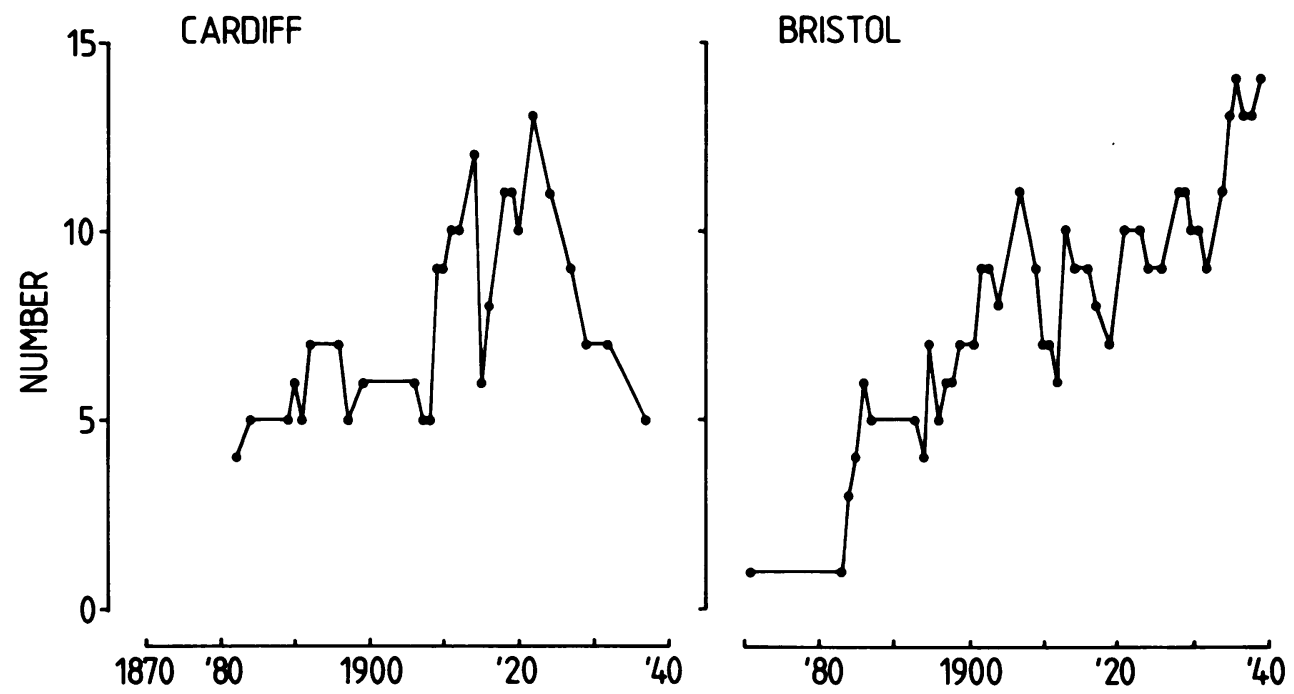

Figure 1 The number of herbalists recorded in directories, between 1870 and 1939, in Cardiff and Bristol.

\footnotetext{
${ }^{3}$ Runs of directories by one publisher or successive publishers taking over the series were used for serial comparison of numbers. For Bristol, Mathews', Wright's Mathews', Wright's, Kelly's (Wright's), and Kelly's directories form an almost complete annual series from 1871 to 1939. For Cardiff, Butcher's, Wright's (Butcher's), Owen's (Wright's), and Western Mail directories annually or biennially from 1882 to 1924, and less frequently until 1937. For counties, Kelly's directory of Monmouthshire and South Wales, between 1871 and 1926; thereafter, Kelly's directory of Monmouthshire' 1934.

4P. Thane, 'Social history 1860-1914', in R. Floud and D. McCloskey (editors), The economic history of Britain since 1700, Cambridge University Press, 1981, vol. 2, p. 212.

${ }^{5}$ Report as to the practice of medicine and surgery by unqualified persons in the United Kingdom, 1910, Cd 5422, p.2.

${ }^{6} \mathrm{~K}$. O. Morgan, Rebirth of a nation: Wales 1880-1980, Oxford University Press 1981, p. 210.
} 


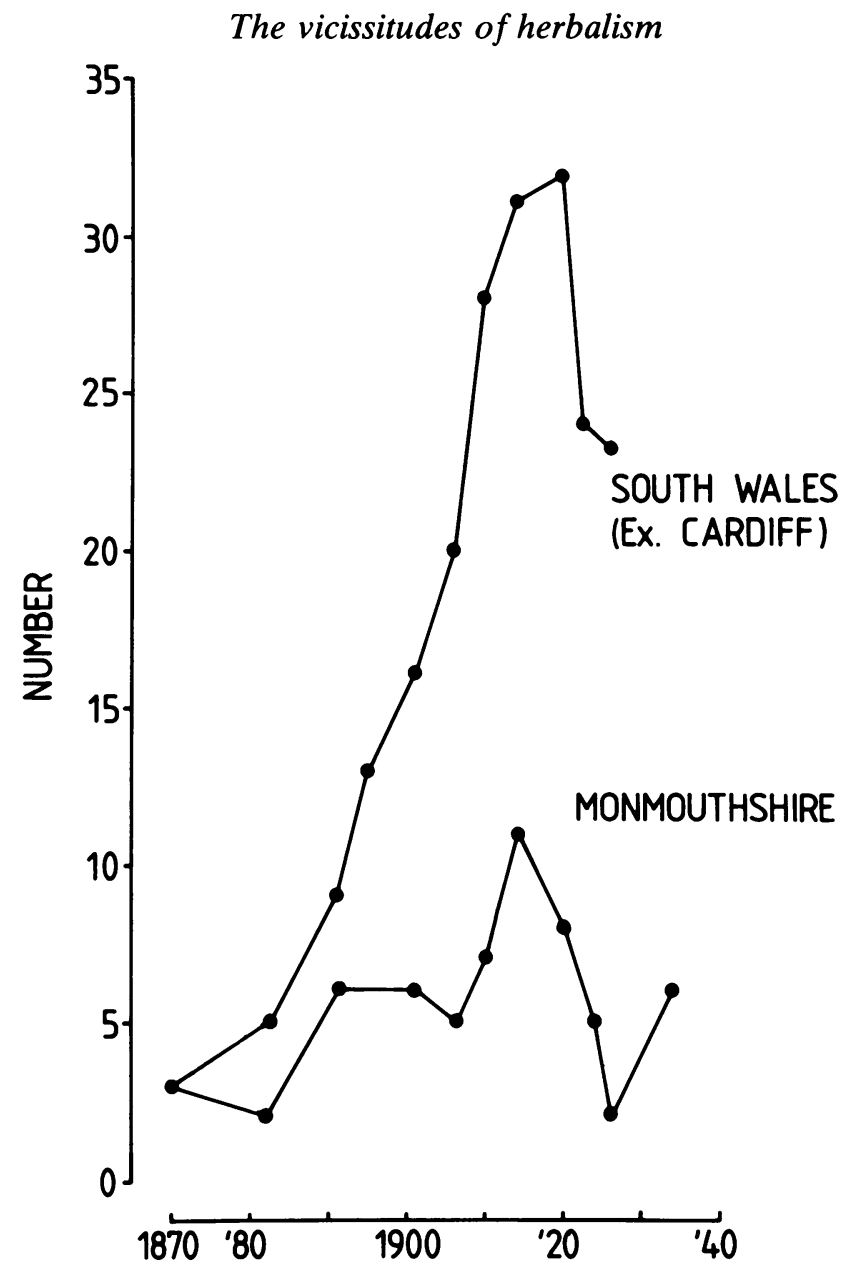

Figure 2 The number of herbalists recorded in directories, between 1870 and 1939, in South Wales (excluding Cardiff) and Monmouthshire.

Directories can also be used to give some estimate of the total number of herbalists in Britain, and a select committee in 1914 was informed that there were "about 1500 herbalists keeping open shop" ${ }^{7}$ A royal commission in 1914 was told that there were about 2500 herbalists and, in 1909, W. H. Webb supposed that there were about $2000 .{ }^{8}$ But not all herbalists appeared in directories and there would in addition have been those who were herbalists part-time or in a very small way of business, as can be seen by examining census returns. In 1871, there was only one herbalist in the Bristol directories but there were ten individuals calling themselves herbalists, herb doctors, or medical botanists in the census enumerators' books. In 1881, there were two

${ }^{7}$ Report of the select committee on patent medicines, 1914, (414), evidence of Joseph Watmore, Q.11617.

${ }^{8}$ Royal commission on venereal disease. Appendix to first report of the commissioners, 1914, Cd 7475, evidence of R. F. Richardson, Q.7790. First report of the departmental committee on the law relating to coroners and coroners' inquests, part 2, 1909, Cd 4782, evidence of W. H. Webb, Q.2122. 


\section{P. S. Brown}

herbalists in the directories and nine in the enumerators' books. ${ }^{9}$

If there were only a few thousand herbalists sufficiently substantial to appear in directories, an even smaller group of professionally committed herbalists obtained membership of one of their associations. The National Association of Medical Herbalists of Great Britain (NAMH) ${ }^{\mathbf{1 0}}$ estimated membership at about 200 in 1882 while, in 1885, the Society of United Medical Herbalists of Great Britain listed 102 members. ${ }^{11} \mathrm{~J}$. P. Dowling, writing in the Light of Day in 1891, estimated that there were 800 bona fide herbalists practising in the United Kingdom. ${ }^{12}$ Numbers remained small in the twentieth century: in 1914, membership of the NAMH was still estimated at 200 and in 1937/38 their journal carried a list of "Qualified medical herbalists" numbering $189 . .^{13}$

Some of these sources also indicate the geographical distribution of the herbalists (see Table 1). In the nineteenth century, they were particularly numerous in the industrial Midlands and the North. The sample of NAMH members quoted in 1882 was probably biased to select those associated with friendly societies, but even a directory of practitioners in the journal of the London college showed a slight northern bias. ${ }^{14}$ In the twentieth century, this distribution was still apparent and, in the first twenty-two years, the annual conference of the NAMH was held seventeen times in the North, twice in Birmingham, and once each in London, Bristol, and Worcester. ${ }^{15}$ The continued concentration of herbalists in the more industrial areas was also shown in the NAMH directory of $1937 / 38,{ }^{16}$ suggesting that their patients were still drawn largely from the industrial working classes. But the balance was shifting towards a more southerly distribution, particularly among the practitioners who considered it worth advertising their "professional cards" in 1939/40. ${ }^{17}$ The shift to the South has become obvious among contemporary practitioners (included in Table 1 for comparison). ${ }^{18}$

\footnotetext{
${ }^{9}$ Methods and geographical definitions for studies of enumerators' books were as used previously, see Brown, op. cit., note 1 above.

${ }^{10}$ The NAMH is now the National Institute of Medical Herbalists and I am grateful to the Institute for access to minutes of early twentieth-century meetings of the NAMH. I am particularly grateful to $\mathrm{Mr} \mathrm{H}$. $\mathrm{H}$. Zeylstra, Director of Education, and to Mrs K. A. Jeffs, Hon. Treasurer of the Institute, for their help and provision of material and facilities.

${ }^{11}$ Report of the royal commissioners appointed to inquire into the Medical Act 1882, Cd 3259, evidence of F. W. Crick. Society of United Medical Herbalists of Great Britian, Year book and transactions with directory of members, Manchester, 1885. Later the two societies amalgamated but overlap of membership was probably not great at this time.

12 Light of Day, 1891/92, 1: 26.

${ }^{13}$ Richardson, op. cit., note 8 above, Q. 7514. 'Directory of qualified medical herbalists', Medical Herbalist, 1937/38, 13: 212, 236, 264; and Health from Herbs Magazine and Medical Herbalist (hereinafter cited as Hlth Herbs med. Herb.), 1938/39, 1 (NS): 108. Herbalists were listed under towns arranged alphabetically, but none appears after listing for Treorchy. (I am grateful to Dr John B. Griggs, Librarian, The Lloyd Library and Museum, Cincinnati, for supplying parts of journals not found in British libraries but needed to check this point.)

${ }^{14}$ 'Herbal practitioners' directory', Light of Day, 1891/92, 1: 64, 80, 96, 112, 128.

${ }^{15}$ NAMH minutes (see note 10 above), 10 May 1923.

16 'Directory of qualified medical herbalists', op. cit., note 13 above.

17 'Professional cards', Hlth Herbs med. Herb., 1939/40, 2 (NS): end pages.

${ }^{18}$ National Institute of Medical Herbalists, Register of members, 1983. I am grateful to Mr M. McIntyre, their Public Relations Officer, for this material. Only members in practice have been counted.
} 
TABLE 1. NUMBERS AND GEOGRAPHICAL DISTRIBUTION OF MEMBERS OF VARIOUS HERBALIST ORGANIZATIONS

\begin{tabular}{|c|c|c|c|c|c|c|c|}
\hline \multirow[t]{2}{*}{ Date } & \multirow{2}{*}{$\begin{array}{l}\text { Organizations and } \\
\text { description of lists. } \\
\text { (References are to } \\
\text { numbered notes to text) }\end{array}$} & \multirow{2}{*}{$\begin{array}{c}\text { Total } \\
\text { number }\end{array}$} & \multicolumn{5}{|c|}{ Distribution. Number of addresses in- } \\
\hline & & & $\begin{array}{c}\text { Industrial } \\
\text { Midlands } \\
\text { (Birmingham, } \\
\text { Coventry, } \\
\text { Black Country) } \\
\text { and England } \\
\text { north of this }\end{array}$ & $\begin{array}{l}\text { England } \\
\text { south of } \\
\text { Birmingham }\end{array}$ & $\begin{array}{l}\text { Wales } \\
\text { and } \\
\text { Mons. }\end{array}$ & Scotland & $\begin{array}{c}\text { Elsewhere } \\
\text { or } \\
\text { uncertain }\end{array}$ \\
\hline 1882 & $\begin{array}{c}\text { NAMH. Estimated } \\
\text { membership } \\
\text { NAMH. Sample of } \\
\text { membership }\end{array}$ & $\begin{array}{r}200 \\
92\end{array}$ & 80 & 9 & 0 & 0 & 3 \\
\hline 1885 & $\begin{array}{l}\text { United Society. } \\
\text { Membership list }^{11}\end{array}$ & 102 & 76 & 15 & 2 & 3 & 6 \\
\hline 1892 & $\begin{array}{l}\text { Herbal Practitioners' } \\
\text { Directory }{ }^{14} \text { in } \\
\text { Light of Day }\end{array}$ & 49 & 25 & 20 & 0 & 4 & 0 \\
\hline 1914 & $\begin{array}{l}\text { NAMH. Estimated } \\
\text { membership }{ }^{13}\end{array}$ & 200 & & & & & \\
\hline $1937 / 38$ & $\begin{array}{l}\text { Directory of Qualified } \\
\text { Medical Herbalists } \\
\text { in Medical Herbalist }{ }^{13}\end{array}$ & 189 & 106 & 50 & 18 & 8 & 7 \\
\hline $1939 / 40$ & $\begin{array}{l}\text { 'Professional Cards' } \\
\text { in Health from Herbs }{ }^{17}\end{array}$ & 33 & 15 & 14 & 2 & 2 & 0 \\
\hline 1983 & NIMH. Membership list ${ }^{18}$ & 113 & 36 & 63 & 3 & 2 & 9 \\
\hline
\end{tabular}

Indications of local change can also be detected, for example, in Bristol where new addresses for herbalists appearing in directories in the 1930s broke new ground with invasion of the fashionable areas-by the Society of Herbalists in Park Street and a herbalist in Portland Place, Clifton. Even so, one active member of the NAMH ${ }^{19}$ never appeared as a herbalist in the local directories, but was listed as a masseuse working in Clifton from 1921 to 1960 . Practising as an ancillary to orthodox medicine seems at this time to have been socially and professionally more desirable in this fashionable area than advertising as a herbalist.

\section{DIVERSITY}

A major problem in characterizing the herbalists was their diversity. Variation was considerable even among herbalists recorded in directories: for example, of the 104 herbalist businesses identified in Bristol, Cardiff, and Newport, ${ }^{20}$ nearly a quarter

${ }^{19}$ Dorothy L. Pratt, (Letter), Medical Herbalist, 1933/34, 9: 212-213; 'Achievement', ibid., 1934/35, 10: 68-70; ibid., 1937/38, 13: 212.

${ }^{20}$ Sources listed in note 3 above, supplemented by data from John's Newport directory (50 issues between 1878 and 1939). 


\section{P. S. Brown}

could be traced for one year only but, in contrast, two could be followed for more than a century while nearly a quarter could be traced for at least twenty years. Long-lasting businesses often represented the practice of succeeding generations of the same family and the well-established practitioners were often prominent members of their local community, as the NAMH emphasized in its petition for a Royal Charter. ${ }^{21}$ The association was quick to congratulate the herbalist who was elected to county or city council or as an alderman or mayor. ${ }^{22}$ An interesting appointment in view of medical opposition was that of Thomas Ramsden as chairman of the Health and the Maternity and Child Welfare Committees of Wigan corporation. ${ }^{23}$

Unfortunately, not all herbalists were of this calibre and it was admitted that: "We have all met with Herbalists in name, who use so noble a title to serve as a guise for immoral and oft-times illegal practices. There is no copyright in the word Herbalism, and thus all who will may use it, and the name has oft been dragged through mud and shame ..."24 The government report on unqualified medical practice in 1910 stated unambiguously of herbalists that "A large number sell drugs for the purpose of procuring abortion, often at exorbitant prices". ${ }^{25}$ Certainly, many persons describing themselves as herbalists were accused of attempting to induce abortion by various means. ${ }^{26}$

The different faces of herbalism were often not distinguished but even the report on unqualified practice admitted that in some parts the herbal practitioner had "a higher reputation than qualified men". ${ }^{27}$ The distinction was emphasized at an inquest on a herbalist's patient at Sowerby in 1909. The foreman of the jury insisted that they had known the herbalist for thirty or forty years and had every confidence in him: "He was not a mere quack — not a person continually coming and going — but one who had been brought up among the people, and a very respectable man". ${ }^{28}$ Local indignation was also apparent some years earlier when Samuel Mathews, a Norwich herbalist and former city councillor, was prosecuted under the Apothecaries' Act. ${ }^{29}$ And the contribution of certain herbalists was recognized during the 1914-18 war when some were exempted from military service..$^{30}$

\section{WHAT IS A HERBALIST?}

Despite their diversity, the herbalists appear to have held in common a definable body of beliefs and principles. Some would have been generally acceptable, but other

\footnotetext{
21 'Petition and draft charter of the National Association of Medical Herbalists of Great Britain, Limited', Minut. gen. med. Coun., 1907, 43: 631-641.

${ }^{22}$ NAMH minutes, 27 February 1902, 4 May 1904, 19 and 20 July 1916. Medical Herbalist, 1925/26, 1: 2 .

${ }^{23}$ Ibid., 1929/30, 5: 110.

${ }^{24}$ F. D. Boyce, 'Herbalism-quackery or art?', ibid., 1932/33, 8: 171.

${ }^{25}$ Report, op. cit., note 5 above, pp. 6-8.

${ }^{26}$ See for example Br. med. J., 1880, ii: 352; 1901, ii: 121; 1909. ii: 180; 1915, ii; 694. Med. Press, 1901, 123: 25, 123; 1908, 136: 4, 623. Lancet, 1888, i: 351; 1898, i. 238. Pharm. J., 1870/71, $1: 1041$.

${ }^{27}$ Report, op. cit., note 5 above, pp. 6-8.

28 'Herbalists and the people', Br. med. J., 1909, i: 1393-4.

29 'The prosecution of a herbalist', Med. Press, 1898, 66 (NS): 226.

${ }^{30}$ NAMH minutes, 8 February 1917, 18 December 1919.
} 


\section{The vicissitudes of herbalism}

ideas may have been developed as part of the mechanism of defining herbalism as an entity distinct from orthodox medicine.

Herbalists confined their medication to vegetable substances and avoided the use of inorganic medicines. Benjamen V. Scott explained that the vegetable kingdom furnished an abundance of simple and harmless remedies "operating in harmony with the simple laws of nature", and that "It is also evident that minerals are not necessary. Deny it, and you charge the great Creator with leaving man for more than five thousand years ignorant of a subject closely connected with his happiness . . . namely, medicine; for it was not until the last four hundred years that minerals have been used, and since their introduction man has fallen in physical strength, and disease has increased." 31 Oliver Phelps Brown explained that the appropriate way for the human body to obtain the necessary minerals was through their assimilation into plants, which man then took as food or medicine. ${ }^{32}$ Webb maintained that "Man was never intended to digest crude minerals", and Harold Ward wrote that, "Taken in their crude, unorganised (non-biological) state, they cannot be assimilated and may consequently be definitely harmful". ${ }^{33}$

A further contrast with orthodox medicine was that herbalists used whole plant material or simple extracts, arguing that, "when some active principles of herbs are used separately their therapeutic action is totally different to that obtained when the whole of the properties of the plant in question are employed." 34 Scott, for example, explained that "Lobelia Inflata, so freely used by botanic doctors, contains an alkali which is poison-'Lobelina', but it also contains an acid which destroys its poisonous property; and the two properties, as combined in the plant, form a medicine which is harmless, and yet powerful in rooting out disease.",35

The use of whole plant material was probably increasingly emphasized as the regular practitioners were increasingly successful at isolating active principles. Earlier in the nineteenth century, some British herbalists, such as $\mathbf{J}$. H. Blunt ${ }^{36}$ had advocated concentrates, alkaloids, and resinoids under American Eclectic influence. These were eventually abandoned in Britain as they were in America, and, by the twentieth century, emphasis was strongly on whole plant material. Mrs C. F. Leyel, comparing purified alkaloids and natural herbs, claimed that "the herb in its natural form, with all its tonic substances, unmeasurable as they may be, does produce not only quite different results, but that the cures wrought by their agency, though slower, are more permanent.",37

Another guiding principle of the herbalists was the avoidance of all poisonous medicines, vegetable as well as mineral. Thomsonian herbalists had been aggressive

\footnotetext{
${ }^{31}$ Benjamen V. Scott, The voice of nature to the invalid, 10th ed., Southport, W. H. Webb, [n.d.], p.1.

${ }^{32}$ Oliver Phelps Brown, The complete herbalist, London, Frederick Hale, 1890, p.9.

${ }^{33}$ William Henry Webb, Standard guide to non-poisonous herbal medicine, Southport, [the author], 1916, p.84. Harold Ward, Herbal manual, London, C. W. Daniel, 1936, p.19.

${ }^{34}$ Harry Orbell, 'Herbal therapy', Hlth Herbs med. Herb., 1939/40, 2 (NS): 61-63, 65.

${ }^{35}$ Scott. op. cit., note 31 above, p.11. For differences of opinion on the toxicity of lobelia, see Brown, op. cit., note 1 above.

${ }^{36} \mathrm{~J}$. H. Blunt, The invalid's medical companion and clinical adviser, London, Job Caudwell, 1862, pp. 103-107.

${ }^{37}$ Mrs. C. F. Leyel, Compassionate herbs, London, Faber \& Faber, 1946, p. 14.
} 


\section{P. S. Brown}

critics of the poisons used by the regular practitioners, and the non-poisonous nature of the herbalists' medication has been increasingly stressed ever since. W. H. Webb incorporated the idea into the title of his Standard guide to non-poisonous herbal medicine, ${ }^{38}$ and both he and Watmore explained the principal to governmental committees. ${ }^{39}$ James Parkinson, in his introduction to the National botanic pharmacopoeia (1905), advocated "nature's harmless vegetable products", regretting the modern medical tendency to "The most potent, subtle, irritating and poisonous mineral products, serums and coal-tar derivatives".40

Emphasis on non-poisonous medicines illustrates the herbalists' therapeutic philosophy. They believed that the driving force of nature keeps the human being in health as long as he obeys the simple laws of nature, and brings him back to health if, for some reason, he has become ill. Therapy must aid the processes of nature and never impede them: any poison would impede. In the nineteenth century, Blunt presented botanic medicines as "compatible with the living organism, perfectly safe in their application";41 and Rosen wrote that "no treatment can be effectual and in accordance with the laws of nature, unless we recognise the fact that Physicians, instead of resorting to violent, perturbing, and injurious medication, shall rather seek to wait upon nature, and assist her upon every possible occasion". ${ }^{42}$

In the twentieth century, Dr Sarah Webb explained the principles of physiomedical herbalism - that treatment must be in harmony with Nature and the vital force. ${ }^{43}$ The Rev. Gwernogle Evans and Alfred Hall in The garden of the Lord, claimed that "Herbalism is the only School of Medicine that is based on the Vital theory of life"; and Charles Abbott advocated "medicines assisting the vital force, instead of destroying it" and harmonizing with "the inherent restorative powers of the system".44 And James Parkinson contrasted the herbalist's attempt to "get nearer to Nature in therapeutic medication" with allopathy "which does not follow Nature, but . . . tries to bounce it and still further upset its balance by crude inorganic medicaments". ${ }^{45}$

The herbalists were thus distinguished by their materia medica and their therapeutic principles. Richardson explained that herbalism was "a name given to a medical sect.... It is only in the use of drugs that we differ from allopaths."46 Similarly, Arthur Barker, president of the NAMH, declared that "Our own system of Materia Medica, on which depends our system of the practice of medicine, remains supreme, the cardinal reason for our existence as a separate, distinctive body of healers." 47

${ }^{38}$ Webb, op. cit., note 33 above.

${ }^{39}$ Webb, op. cit., note 8 above. Watmore, op. cit., note 7 above.

${ }^{10} \mathrm{James}$ Parkinson, Introduction to National botanic pharmacopoaeia, compiled by James William Scurrah, Bradford, NAMH, 1905.

${ }^{41}$ Blunt, op. cit., note 36 above, pp. v-viii.

${ }^{42}$ Dr Rosen, Reformed practice of medicine, 10th ed., Nottingham, [the author], 1895, p.8.

${ }^{43}$ Sarah A. Webb, 'The principles of physio-medical herbalism and the vital force', Medical Herbalist, 1932/33, 8: 19.

${ }^{44}$ T. Gwernogle Evans and Alfred Hall, 'The garden of the Lord', ibid., 1935/36, 11: 43-47. Charles Clement Abbott, Rex vs. Abbott, Manchester Assizes, March 29, 1933, Wigan, R. Platt, 1933, p. 7.

${ }^{45}$ James Parkinson, 'The pre-eminence of the botanic system', Medical Herbalist, 1926/27, 2: 124-126.

${ }^{46}$ Richardson, op. cit., note 8 above, Q. 7537. 


\section{The vicissitudes of herbalism}

There were other attitudes common among herbalists but not peculiar to them, which also helped to mark them off from orthodox medicine. Obedience to the laws of nature entailed eating the correct diet, and Scott explained that "Man's food and medicine grow side by side", both being ordained for supporting healthy life. ${ }^{48}$ Herbalists were therefore concerned with food reform, and Younger wrote that "Natural, pure, simple food stuffs should constitute our diet". But neither he nor herbalists such as Webb and Ward were unequivocally vegetarian. ${ }^{49}$ Charles Abbott, on the other hand, opposed the use of flesh foods, but chiefly because "To take the flesh of any animal is to take also the waste products contained therein". ${ }^{50}$ The similar view of a Bristol herbalist was that "Meat is an impure and totally unnecessary form of food". 51

There was greater unanimity over vaccination. Webb told a governmental committee that "Nearly all herbalists are against vaccination; they say it is injecting disease". ${ }^{52}$ They also objected to legal compulsion and, in the $1860 \mathrm{~s}$, the Anticompulsory Vaccination League included herbalists among its officers. ${ }^{53}$ In 1891 , Dowling's Light of Day lamented that "No one knows better than the Medical Herbalists . . . what troubles Vaccination has brought upon the human race"; ;4 and, widening the area of disapproval, Scott wrote in 1927 that the medical profession had "developed a worse than heathenish system of disease treatment by means of vaccines, serums, and anti-toxins, all of which are the products of disease itself, and therefore utterly opposed to sanative healing and Biblical hygiene." 55

The majority of herbalists probably opposed vivisection, but their reasons were theoretical as well as humane. The twentieth-century herbalists often expressed themselves rather briefly on the subject though some may have been passionately committed: Webb, for instance, was an officer of the Anti-Vivisection Society as well as the Anti-Vaccination League. ${ }^{56}$ Arthur Barker claimed that "Herbalism is a clean healing art. The Animal Creation does not cry out loud in an agony of sweat and blood to the Herbalist." ${ }^{57}$ William T. Dawes had been more matter of fact: he did not believe that any good result could be obtained from experiments on animals because "It could not be expected that the mentality and reactions of animals would be the same as those of human beings". ${ }^{8}$

\footnotetext{
${ }^{47}$ A. Barker, 'A momentous session', Medical Herbalist, 1934/35, 10: 117-120.

${ }^{48}$ Scott, op. cit., note 31 above, p.1. See also Sidney L. Smith, 'Food as a factor in the cause and treatment of disease', Medical Herbalist, 1934/35, 10: 15-16.

${ }^{49}$ David Younger, The magnetic and botanic family physician, London, E. W. Allen, 1887, pp. 115, 520-521. Webb, op. cit., note 8 above, Q.2260. Ward, op. cit., note 33 above, p. 21.

${ }^{50}$ C. C. Abbott, $A$ legacy of health, Manchester, S. Harrison, 1934, p. 10.

${ }^{51}$ Dorothy L. Pratt, (letter), Medical Herbalist, 1933/34, 9: 212-213; 'The case for and against vegetarianism', ibid., 1937/38, 13: 144-145.

${ }_{52}$ Webb, op. cit., note 8 above, Q.2268.

${ }^{53}$ They included J. H. Blunt, John Skelton (sen. and jun.), and F. W. Crick, see Eclectic Journal and Medical Free Press, 1866/67, 1: 192.

54 'What we are coming to, or Pasteurism in England'. Light of Day, 1891, 1: 17-18.

${ }^{55}$ B. V. Scott, 'Truth versus authority' in What is a herbalist?, Southport, Lancashire Branch of the NAMH, 1927, p. 9.

so 'William Henry Webb', Medical Herbalist, 1927/28, 3: 218-220.

${ }^{57}$ A. Barker, 'Presidential address', ibid., 1936/37, 12: 21-24.
} 


\section{P. S. Brown}

Opposition to vaccination and vivisection was not peculiar to herbalists: there was even an anti-vivisectionist movement within regular medicine. ${ }^{59}$ But the herbalists' therapeutic principles and associated beliefs and attitudes, taken together, gave them an identity and formed a basis for practice which was characteristic and distinct.

\section{THE CONTINUING AMERICAN INFLUENCE}

Samuel Thomson was a primary influence on British herbalists and an explanation of his materia medica shows their major principles already formulated: "There is no article or plant ever recommended by Dr. Samuel Thomson as a remedial agent ... which contains a particle of narcotine or poison, and which does not harmonize with the laws of life, and aid nature in her efforts to overcome the disease and restore the patient." publications well into the twentieth century. ${ }^{61}$

British herbalists also identified with their American counterparts because of the professional success achieved by the derivatives of Thomsonian medicine. "American doctors" also practised in Britain; for example, Dr Rosen, a Nottingham herbalist who wrote a booklet on the Reformed practice of medicine.$^{62}$ Many British herbalists became interested in Eclecticism and the Eclectic Journal and Medical Free Press, associated with John Skelton and published in Leeds from 1866, explained that "There is a large and growing class of physicians called, at first, after the founder of the school, Thomsonians. Subsequently they were generally known as Botanic Physicians. Now they pass under the title of Eclectics." 63 The journal claimed American connexions and advertised numerous "Eclectic and Botanic" dispensaries and depots in Britain. In 1868, the opening of the Leeds Eclectic School of Medicine was announced and, next year, that of the British Eclectic Medical College ${ }^{64}$ British Eclecticism was probably short-lived, but echoes of its popularity continued through the century. ${ }^{65}$

In the twentieth century, the British herbalists were in contact with the American Physio-Medical movement. Most influential in this liaison was William Henry Webb, who ran a Botanic Sanatorium at Southport, where American practitioners paid visits and lectured. ${ }^{66}$ One of them, addressing the NAMH, explained that "PhysioMedicalism in America is the same as Herbalism in England". ${ }^{67}$ Webb announced to

${ }^{58}$ W. T. Dawes, 'Presidential address', ibid., 1933/34, 9: 22-27.

${ }^{59} \mathrm{~F}$. Honigsbaum, The division of British medicine, London, Kogan Page, 1979, pp. 162-170.

${ }^{60}$ Lobelia Advocate, 1838, reproduced in Bull. Lloyd Libr., 1909, 11: 75-76.

${ }^{61}$ See Medical Herbalist, 1925/26, 1: 98, and Hlth Herbs med. Herb., 1938/39, 1 (NS): 155. Webb named Thomson in the subtitle of his Standard guide, op. cit., note 33 above.

${ }^{62}$ Rosen, op. cit., note 42 above.

63 'Eclectics', Eclectic Journal and Medical Free Press, 1866/67, 1: 201-202.

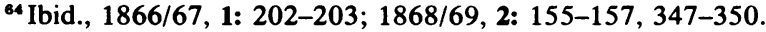

${ }^{65}$ The United Society recommended American Eclectic textbooks for its students, see Year book, op. cit., note 11 above. A British and International Association of Eclectic and Medical Botanists is mentioned in Light of Day, 1891/92, 1: 1. See also T. Garbutt, Eclectic physican, Bridlington, [the author], 1898

${ }^{66}$ See Medical Herbalist, 1927/28, 3: 218-220; 1936/37, 12: 27-29. Webb, op. cit., note 33 above, p. vii.

${ }^{67}$ NAMH minutes, 26 July 1906. 
the NAMH conference in 1904 that the Physio-Medical College of Indiana had offered courses of training to anyone recommended by the NAMH. ${ }^{68}$ In reply, the meeting sent "Fraternal greetings to the Physio-Medical Congress of America", but it is unlikely that the British herbalists appreciated the problems the Americans were having. In 1902-3, the Physio-Medical College of Indiana had enrolled only twentynine students and was not recorded in 1910 when Flexner's report on American medical education could dismiss the "physio-medical sect" in a footnote. ${ }^{69}$

In Britain, the American influence persisted, perhaps the clearest evidence being provided by the British herbalists' materia medica. They adopted many plants of American origin, including many of Thomson's main medicines as well as some used by Eclectics and others. The herbalists who did not adopt the new materia medica were the exceptions. ${ }^{70}$

\section{THE STRUGGLE FOR PROFESSIONAL STATUS}

While British herbalists looked wistfully at the United States, their failure to unite in a cohesive group impeded any successful pursuit of professional status. Societies abounded but the one which emerged as the most long-lasting and, despite its conservatism, the foremost in the struggle for recognition was the NAMH. ${ }^{\text {.1 }}$ The main alternative in the nineteenth century was the Society of United Medical Herbalists of Great Britain (the United Society), founded around 1877 and centred on Rochdale. ${ }^{72}$ The United Society may have achieved some unity: one meeting, at which the president of the General Council of Safe Medicine was made a member, was addressed by the president of the NAMH. ${ }^{73}$

Herbalists aspiring to professional status needed to dispel some elements in their traditional image. First, it had become necessary to purge herbalism of association with astrology. Phelps Brown can be seen adjusting his position between the 1871 and 1890 editions of his Complete herbalist, ${ }^{\mathbf{7 4}}$ and Robinson, in his New family herbal (1920), commented that "The government of Herbs by the sun, moon, and planets, has been exploded by modern science; and is now regarded by persons of ordinary capacity to be absurd in the extreme". ${ }^{75}$ Most herbalists agreed, and Webb used the expression "Culpeperism" to distinguish and discard the astrological implications of that author. ${ }^{76}$

\footnotetext{
${ }^{68}$ Ibid., 21 July 1904.

${ }^{69}$ J. Am. med Ass., 1903, 41: 439. Abraham Flexner, Medical education in the United States and Canada, New York, Carnegie Foundation, 1910, p. 163.

${ }^{70}$ Ample evidence for this claim can be drawn from a study of British herbalists' publications but will not be detailed here.

${ }^{71}$ The seniority of the NAMH, founded in 1864, was acknowledged by the appointment of its representative, Harry Orbell, as first president of the International Association of Medical Herbalists, see Hlth Herbs med. Herb., 1942/43, 5 (NS): 493.

${ }^{72}$ Year book, op. cit., note 11 above. Some other nineteenth-century societies have been mentioned elsewhere in this paper, and the multiplicity of twentieth-century associations is discussed separately below.

${ }^{73}$ 'Herbalists in conference', Lancet, 1894, i: 1203-1204.

${ }^{74}$ O. P. Brown, The complete herbalist, London, [ the author], 1871, pp. 10-26; idem, 1890 edition, op. cit., note 32 above, pp. 8-22.

${ }^{75}$ Mathew Robinson, The new family herbal, London, W. Nicholson, 1920, p. 5.
} 
The next embarrassment was the image of the old-fashioned herbalist's shop. Lady Simson, of the Society of Herbalists, irritated the NAMH by a newspaper article implying that herbalists were disreputable old people practising in the market place or behind the worm-eaten counter of a stuffy little shop; ${ }^{77}$ while Sir Ernest Wallis Budge described a small, dirty, and ill-lit herbalist's shop of the nineteenth century, decorated with skulls and a dried crocodile. ${ }^{78}$ And Albert Orbell has recalled the early twentieth century, when few herbalists had consulting rooms and most patients were seen over the counter. ${ }^{79}$

Just as the regular general practitioner had evolved partly by the apothecary deserting his counter, so the herbal practitioner with professional aspirations felt it necessary to dissociate himself from the herbalist's shop. K. Culpan, addressing the NAMH in 1920, suggested that a better name would have been the National Association of Herbal Practitioners, but continued:

I do not mean for one moment that men who do not attend the sick, but prefer to keep a shop,
should or would not be eligible for membership. No. The man who retails and supplies is a
necessary adjunct to the man who visits and prescribes, just as much as, if not far more so, than
the chemist is to the medical practitioner. The welfare of the one is bound up with the welfare of
the other, and it is the bounden duty of the Association to look to the advantage of both sections
equally. I do contend, however, that attendance on the sick is intended to be first and
foremost.

But there were probably many members of the NAMH at that time who could not risk abandoning their shops to seek a living purely in consulting practice.

In claiming a particular expertise and specialized knowledge, the herbalists' characteristic materia medica was an important item-but also a contentious one. A herbalist might remark that "Medical men know as much about herbs as a cat knows about the moon", ${ }^{81}$ but the regular practitioners considered their advice to be "founded not only on a complete knowledge of herbs, but of the human body and its diseases as well".82 The pharmacists also contested the herbalists' claim to exclusive expertise..$^{83}$ And, at the start of the twentieth century, information about the herbalists' materia medica was mostly buried in books written many years earlier. The NAMH therefore decided to issue the formal, up-to-date and "official" National botanic pharmacopoeia (1905). ${ }^{84}$

Similar problems existed with textbooks. In the 1880 s, when the NAMH and the United Society recommended books for their students, the only British works on

\footnotetext{
${ }^{76}$ Webb, op. cit., note 33 above, pp. vii-viii. The expression "Culpeperism" was also used by Ward, op. cit., note 33 above, pp. 9-16. But see also, H. Orbell, 'Herbalists and astrology', Health Practitioners Journal, 1938/39, 2: 211.

${ }^{77}$ Medical Herbalist, 1931/32, 7: 141-144.

${ }^{78}$ E. A. Wallis Budge, The divine origin of the craft of the herbalist, London, Society of Herbalists, 1928, pp. 5-6.

79 'An excerpt from the memoirs of Mr. Albert Orbell', Herbal Review, 1980, 5: 12-15.

${ }^{80} \mathrm{~K}$. Culpan in What is a herbalist?, op. cit., note 55 above, pp. 23-24.

81 'Herbalist's claim', Med. Press, 1916, 51 (NS): 432.

82 'Herbalists and the people', Br. med. J., 1909, i: 1393-1394.

ss 'Herbalists, pharmacists and medical men', Pharm. J., 1906, 23 (4th ser): 213. Report, op. cit., note 7 above, evidence of E. F. Harrison, Qs. 3451, 3457, 3459.

${ }^{84}$ Pharmacopoeia, op. cit., note 40 above.
} 
herbalism included were those of Skelton. ${ }^{85}$ Webb and Watmore, in 1909 and 1914, could add the new pharmacopoeia to the list, but Webb's Standard guide (1905) still depended heavily on reprinted American material. ${ }^{86}$ The NAMH had tackled the problem of a textbook by purchasing the rights to the material in John Skelton's Science and practice of medicine, which they published as a considerable volume in $1904 .^{87}$ But Skelton had died in 1880 , and it is not clear how much the material had been re-worked for publication. A herbalist might therefore still complain in 1929 that "We are sadly deficient in published works. We have none written by men of authority possessing British medical and scientific qualifications, works written from the standpoint of botanic medical practice which can be used as text books or students' manuals."

An aspiring profession also required a journal. Those associated with Skelton and Dowling have been mentioned, and other herbalist journals had existed, but usually briefly. The NAMH published the Botanic Practitioner but this was replaced by the Herbalist in $1902 .^{89}$ In the next decade, they were apparently without a journal so that the first issue of the Medical Herbalist in 1925 was greeted with enthusiasm. Well edited and well produced, it justified the president's comment that its publication "will give us a literary status which we have not hitherto had". ${ }^{90}$ Later, the NAMH accepted an offer of S. L. Smith's Health from Herbs which was combined with the Medical Herbalist in 1938 as a more popular publication and, in 1940, the Herbal Practitioner was initiated as a professional journal. ${ }^{91}$ And early in the twentieth century, the ever-active W. H. Webb edited the Herb Doctor, which was the official publication of the People's League of Medical Freedom. ${ }^{\mathbf{2}}$

To professionally aspiring herbalists, competition with the vast resources behind established medicine was a daunting prospect. Orthodox "medical research", for instance, was a powerful challenge to meet. Appreciating its importance, the NAMH initiated a medal for the best paper reporting original research read at the annual conference and, in 1912, had the temerity to apply to the National Insurance Commissioners for money for "Medical Research on herbal lines, out of the money to be set aside for that purpose"..$^{93}$ In 1930, a sympathetic Member of Parliament urged all unorthodox practitioners "to enter upon research vigourously", but it was pointed out in a parliamentary debate that the practitioner without a regular qualification had "no opportunities for research, no hospital base for the observation

${ }^{85}$ Crick, op cit., note 11 above. Year book, op. cit., note 11 above, pp. 9-12.

${ }^{88}$ Webb, op cit., notes 8 and 33 above. Watmore, op. cit., note 7 above.

${ }^{87} \mathrm{John}$ Skelton, sen., The science and practice of medicine, London, NAMH, 1904. NAMH minutes, 9 April, 16 July, 3 December 1903.

${ }^{88}$ R. O. Daine, 'The herbalists' constitution', Medical Herbalist, 1929/30, 5: 35-36.

${ }^{89}$ NAMH minutes, 27 February 1902, 15 January 1903.

${ }^{90} \mathrm{~J}$. Watmore, Medical Herbalist, 1925/26, $1: 1$.

${ }^{91}$ NAMH minutes, 8-11 July 1935. Health from Herbs Magazine and the Medical Herbalist appeared with a new format and editorial explanation of aims.

${ }^{92}$ The League, founded in 1906 , was not specifically herbalist. Its aims were described by Webb, op. cit., note 8 above, Qs. 2110-2122. It was actively supported by the NAMH which subscribed to its funds (see NAMH minutes, 21 March 1918, 8 December 1921, 18 November 1931) and encouraged membership (see NAMH minutes, 18 December 1919 and Culpan, op. cit., note 80 above, p. 27). For the medical profession's view of the Herb Doctor, see Br. med. J., 1908, i: 1254; 1911, i: 1275-1276.

${ }^{93}$ NAMH minutes, 22 July 1908, 5 December 1912. 


\section{P. S. Brown}

of patients and no staff of research workers behind him."94 In 1941, a difficult time for herbalism, the NAMH formed a research department in the charge of F. Fletcher Hyde, a herbal practitioner with a first-class science degree, thus ensuring a professionally scientific approach to the herbal materia medica. ${ }^{95}$

Herbal practitioners recognized the need for formal training, and societies with sufficient resources founded schools or colleges. The Eclectic College in Leeds has been mentioned and, in 1884, the United Society founded its School of Medicine at Rochdale. ${ }^{96}$ Presumably, these institutions had failed by 1891 when J. P. Dowling became president of the Metropolitan Medico-Botanic College, opened under the auspices of the British and International Association of Medical Herbalists. In justifying its location, Dowling wrote that training institutions in the provinces had "been opened, lingered on for a time, and eventually collapsed". The London college outlined a three-year course of instruction, and also planned postal tuition. ${ }^{97}$ It is uncertain how long this college lasted but in 1893 its first dean, David Younger, founded the Magnetic and Botanic School of Safe Medicine, and the General Council of Safe Medicine, Limited. ${ }^{98}$

As in other professional matters, the NAMH made the best showing at maintaining an educational organization, though progress was fitful. In 1901, Webb provided space for a school in his Southport premises but there were problems and, before the end of the decade, proposals were made for a school at Birmingham or Sheffield.99 In 1910, Webb again offered part of a house in Southport where a training college was officially opened in 1911. Again, there were difficulties, and a few years later a correspondence course was initiated. ${ }^{100}$ But the need for sound training facilities was a constant priority and, in 1931, the NAMH opened the College of Botanic Medicine in London. Its history, until closure in 1940, has been detailed by Griggs. ${ }^{101}$

The herbalists realized that educational qualifications alone were not sufficient. In view of the many disreputable individuals who sheltered under the title of herbalist, they were anxious that membership of their societies should carry a guarantee of moral character. Entry to examinations of the NAMH, for example, was allowed after candidates had been approved from the point of view of their training and of their character and respectability. ${ }^{102}$ Similarly, before granting their degree, the General Council of Safe Medicine satisfied themselves that the candidate sustained a good moral character. ${ }^{103}$ The very title of the council was presumably chosen to suggest a professional self-disciplining body analogous to the General Medical

\footnotetext{
${ }^{94}$ R. J. Wilson, letter recorded in NAMH minutes, 4 September 1930. Capt. Elliston, Parliamentary Debates, Commons, 1936, 310: 1578.

${ }^{95}$ Hlth Herbs med. Herb., 1940/41, 3 (NS): 324. See also Medical Herbalist, 1931/32, 7: 26.

${ }^{96}$ Year book, op. cit., note 11 above, pp. 9-11.

${ }^{97}$ Light of Day, 1891/92, 1: 1-5, 34, 93.

${ }^{98}$ Times Law Reports, 1904, X: 483-484.

${ }^{99}$ NAMH minutes, 26 November 1901, 27 August 1908, 21 April 1910. Later, Nottingham was considered, see ibid., 16 October 1913.

${ }^{100}$ NAMH minutes, 21 April 1910. Medical Herbalist, 1930/31, 6: 1.

${ }^{101}$ Griggs, op. cit., note 2 above, p. 274.

${ }^{102}$ See discussion of candidates in NAMH minutes, passim.

${ }^{103}$ Times Law Reports, 1904, X: 483-484.
} 
Council (GMC). The NAMH committees examined cases of "unprofessional conduct", and a practitioner involved in the "Bootle baby sensation" was struck from membership. ${ }^{104}$ The herbalists tried hard to set professional standards in both skill and conduct, but without some statutory recognition these could never be enforced.

\section{OPPOSITION}

Opposition came from the medical profession both directly and indirectly because, as the herbalists pointed out, "For years the people of England, and especially those in authority, had been dominated by the opinions of the medical fraternity" ${ }^{105}$ The regular practitioners sometimes tried to dismiss herbalism with a patronizing attitude: a leader in the British Medical Journal wrote of the herbalist that "We should almost be sorry if he and his stock of dried plants disappeared from the humbler walks of life in which he moves". ${ }^{106}$ But when the herbalists sought official recognition, medical opposition was solid. The position of the regular profession was defended by the Apothecaries' Act and the Medical Act, the latter making it illegal for an unregistered practitioner to assume a title which suggested that he was registered. Consequently, the General Council of Safe Medicine ran into trouble by awarding the degree of $\mathrm{MD}(\mathrm{Bc})$. Joseph Steel, of Durham, was convicted for using this degree as it suggested he held a registrable qualification. Steel lost an appeal, the judges calling Younger's Council a "bogus institution". The GMC then obtained a writ preventing the General Council of Safe Medicine from awarding this degree or any like it. ${ }^{107}$

Herbalists might be prosecuted on the same grounds if they used titles such as MD(USA) when, for example, they held an MD of the Eclectic Medical College of Pennsylvania. ${ }^{108}$ But prosecution of herbalists was not systematic and probably occurred only when triggered by a particular circumstance. An obvious instance involving Charles Burden, secretary of the NAMH, is described below, but one wonders what was the trigger when Samuel Mathews, the well-established Norwich herbalist, was fined on one day for using the title of surgeon and next day prosecuted under the Apothecaries' Act. ${ }^{109}$ Herbalists sometimes invoked an Act of 1548 (34 \& 35 Henry VIII) which appeared to give them the right to practise. J. C. Purdue used it successfully against the Society of Apothecaries in 1901: but they did not fail to

\footnotetext{
${ }^{104}$ NAMH minutes, 27 August and 2 December 1908, 26 and 27 February 1936.

${ }^{105} \mathrm{Br}$. med. J., 1923, ii: 213. A non-medical member of the Royal Commission, op. cit., note 8 above, (Q.7658), asked the herbalist witness, "Then do you dispute that the effect of herbalism as a system is to stereotype the inchoate stage of pharmaceutical knowledge and to retard the development of medicine?".

106 'Herbalists and herbalism', Br. med. J., 1923, ii: 250-251.

${ }^{107}$ Times Law Reports, 1904, X: 483-484. Minut. gen. med. Coun. (for 1895), 1896, 32: 165-166, 176-178.

${ }^{108}$ 'Important case-Prosecution of a botanic practitioner', Med. Times Gaz., 1871, 2: 755-756. Some American MDs appear to have been awarded purely on payment, see Report, op. cit., note 11 above, evidence of J. S. Billings (Q.4852), and L.LeM. Minty, The legal and ethical aspects of medical quackery, London, Heinemann, 1932, pp. 50-54. Some herbalists avoided the forbidden title of "doctor" by using "professor" instead. They were not usually in the top rank of professional herbalists, but this was not always the case.

${ }^{109}$ 'A herbalist in trouble', Lancet, 1898, ii: 587.
} 


\section{P. S. Brown}

convict him when they tried again two years later. ${ }^{110}$

The Apothecaries' Act rendered herbalists liable to "repeated and vexatious prosecutions" while the Medical Act theoretically excluded them from acting for friendly societies and clubs. But many herbalists held club appointments "by the unanimous desire of the members" and numerous friendly societies accepted their certificates. ${ }^{111}$ To consolidate their position the herbal practitioners needed some form of official recognition such as a Royal Charter. Dowling had intended to apply as soon as his college was established, but a formal petition for a Royal Charter was eventually made by the NAMH in $1906 .{ }^{112}$ It was unsuccessful because of the solid opposition of the medical establishment, the GMC claiming that the NAMH could give no evidence of its competence to act as an examining and controlling body, and that granting the privileges it requested would defeat the purposes of the Medical and Pharmacy Acts. The British Medical Association also objected that such a charter would deprive the public of the protection they obtained from these Acts; and the Pharmaceutical Society added that the council of the NAMH had no special knowledge to examine in botany, materia medica, or pharmacy. ${ }^{113}$ But despite their firm opposition, there was little suggestion that the medical profession was greatly alarmed.

The herbalists were not deterred for long and, spurred on by their problems over National Health Insurance, in 1913 they revived their agitation for formal recognition. Their efforts were interrupted by the war, but a Bill for Registration of Medical Herbalists was finally presented in 1923. A General Medical Herbalist Council of members appointed by the Privy Council, the Minister of Health, the Board of Education, and the $\mathrm{NAMH}$, was to regulate registration and impose penalties for unauthorized use of the title of registered medical herbalist. A leader in the British Medical Journal called it a parody of the Medical Act, but again no great alarm was suggested. ${ }^{114}$ And the medical complacency was justified: the Bill never received a second reading.

The herbalists, understandably aggrieved, complained that they were not simply unqualified medical practitioners but were duly qualified representatives of a different school of medical thought. ${ }^{115}$ But they lacked political power and, in 1927, the president of the NAMH confessed that "there have been occasions when depression has siezed me, and I have realised how powerful are the forces arrayed against us". ${ }^{116}$ But characteristically the herbalists did not give up and, after the

\footnotetext{
${ }^{110} \mathrm{Br}$. med. J., 1901, ii: $1492 ; 1903$, i: 231 . In 1937, repeal of the 1548 Act was suggested but not obtained, see Parliamentary Debates, Commons, 1937, 319: 1296.

${ }^{111}$ Report, op. cit., note 11 above, document presented by NAMH and appendix to Crick's evidence. An analogous situation occurred later, see Parliamentary Debates, Commons, 1914, 62: 913.

${ }^{112}$ Light of Day, 1891/92, 1: 2. Minut. gen. med. Coun., 1907, 43: append.XVI, 631-637.

${ }^{113}$ Minut. gen. med. Coun., 1907, 43: 637-641. Pharm.J., 1906, 24, (4th ser): 213-214. A comment in Med. Press, 1905, 79 (NS): 464, was that "The annals of brazen quackery could hardly furnish a more contemptuous disregard of the rights of legitimate medicine."

${ }^{114}$ NAMH minutes, 24 April 1913, 23 April 1914, 29 April 1915. Lancet, 1923, i: 877, 933. Br. med.J., 1923, ii: 250 .

${ }^{115}$ NAMH minutes, 18 December 1919. Culpan, op. cit., note 80 above, p. 23.

$116 \mathrm{~J}$. Watmore, Medical Herbalist, 1927/28, 3: 2-9.
} 
College of Botanic Medicine had been running for a year, wrote to the Minister of Health requesting that he receive a deputation to discuss their "registration as a teaching and practising body". The letter was passed to the GMC after the minister had replied that he would not support a bill for statutory recognition and saw no point in receiving a deputation. ${ }^{117}$

While herbalism faced repeated failures to achieve official recognition, it was also threatened by the extension of orthodox medicine's monopoly. First, there was the National Health Insurance Bill of 1911, under which insured persons were to register with one of a panel of medical practitioners. At first, it seemed as if this would not constitute a medical monopoly because the Home Secretary implied that a person might choose to register with a duly qualified herbalist, and the answer to a parliamentary question emphasized that whether this was allowed depended entirely on the local insurance committee. ${ }^{118}$ The possibility was tested in Worcester, where Charles Burden practised. The Worcestershire county insurance committee was unwilling to allow applicants to arrange for medical care with herbalists, because they could not operate or sign death certificates. But Worcester city committee in July 1913 allowed applicants to make arrangements with Burden, the decision being carried by a good majority (fifteen to nine). ${ }^{119}$

Burden's success was a challenge to the medical profession and by late 1913, Worcester doctors were threatening him with prosecution. ${ }^{120}$ An inquest on one of Burden's patients in February 1914 gave them their opportunity. The inquest received detailed coverage in the medical journals and, in May, Burden was successfully prosecuted under the Apothecaries' Act, and subsequently lost an appeal. ${ }^{121}$ If other insurance committees allowed contracts with herbalists these cases received less publicity, and the possibility of making such contracts was removed by action initiated in 1914 by the GMC, which ensured that new regulations for implementing the insurance Act specifically excluded such arrangements. ${ }^{122}$

The next legislation to extend the medical monopoly was the Venereal Disease Act (1917), which forbade treatment except by qualified medical practitioners. The secretary reported to the Annual conference of the NAMH that, "through the influence of the Medical Profession we have had a bit more of our liberties taken from us in the passing of the Venereal Disease Act. This is clearly a start to absolute monopoly in medicine by the Allopaths. They are known to say that in five years none but the registered man will be able to practise medicine. A more outrageous piece of legislation has never passed the Houses of Parliament than this 'Venereal Disease Act'." ${ }^{123}$ The Act probably damaged the least professional herbalists but, as

\footnotetext{
${ }^{117}$ Minut. gen. med. Coun., 1933, 69: 118-119. Parliamentary Debates, Commons, 1932, 269: 1962; 1932, 270: 511 .

${ }^{118}$ Ibid., 1913, 52: 1288-9; 1914, 62: 913.

${ }^{119}$ Lancet, 1913 , i: 1705 ; 1913, ii: $1359-60 . \mathrm{Br}$. med. J., 1913, ii: suppl. 75.

${ }^{120}$ NAMH minutes, 4 December 1913.

${ }^{121}$ Berrow's Worcester Journal, 14 February, 16 May, 7 November 1914. Lancet, 1914, i: 561-562. Br. med. J., 1914, i: 407, 1160.

${ }^{122}$ Minut. Gen. Med. Coun., 1915, 51: 261-267. It must have been before the new regulations were in force that the Worcester committee (by majority of only one vote) allowed two applicants to register with a herbalist in 1915, see Br. med. J., 1915, i: suppl. 46.

${ }^{123}$ NAMH minutes, Secretary's annual report, July 1917 (loose in minute book).
} 
the president of the NAMH pointed out, for many herbal practitioners treatment of venereal disease had been "practically non-existent". ${ }^{24}$

The Medicines and Surgical Appliances (Advertisement) Bill, introduced in 1936, was the next apparent threat. One of its aims was to make any claim to cure Bright's disease, tuberculosis, diabetes, cancer, or epilepsy an offence. Its proposer disclaimed any intention of damaging unorthodox practitioners such as osteopaths and herbalists, whose "excellent work" he recognized: but the herbalists believed that the bill, if passed, would "shut down some 15,000 health practitioners". ${ }^{125}$ The validity of this prediction was never tested because at its second reading, on the afternoon of the Grand National horse race, the bill was counted out. ${ }^{126}$ But the Pharmacy and Medicines Act (1941) was passed quickly. Despite repeated assurances during debate that it would not interfere with the practice of legitimate herbalists, the Act severely limited what herbalists might sell. The resulting situation was detailed by the Society of Herbalists, which had been active in trying to prevent its passage. ${ }^{127}$

The final blow to herbal practice came with the arrival of the National Health Service. ${ }^{128}$ The earlier National Health Insurance had not provided medical cover for the dependents of insured persons, but the new scheme was comprehensive.

\section{THE PROSPECT FOR HERBALISM IN THE 1930s}

Despite the reverses of the early twentieth century, the herbalists did not disappear. In Bristol, their numbers in directories continued to climb right up to 1939, and the president of the NAMH claimed in 1937 that "The public are turning in ever increasing numbers to the benefits of Medical Herbalism and I venture to say that over 100,000 patients are treated annually by members of this Association". ${ }^{129}$ Even the advent of the comprehensive National Health Service has not extinguished herbalism and, in the last quarter of the present century, it seems that herbal practice is thriving, though reliable data are hard to obtain. The survey by Fulder \& Monro provided evidence of the contemporary expansion of "complementary medicine" in general, but obtained little information about herbal practice. ${ }^{\mathbf{1 3 0}}$

Herbalism has had to adapt to social change but the therapeutic philosophy which holds the secret of its present attraction represents much of the system's traditional thought. Herbalism has strong conservative and traditional elements, but adaptive changes were needed in the twentieth century and the impact of more radical views made the decades between the wars, and particularly the 1930s, a time of excitement

${ }^{124}$ Culpan, op. cit., note 80 above, p.23.

${ }^{125}$ Parliamentary Debates, Commons, 1936, 310: 1569-70. 'Health practitioners' league', Medical Herbalist, 1935/36, 11: 170. The Cancer Bill caused similar alarm and an emergency notice in Hlth Herbs med. Herb., 1938/39, 1 (NS): 191.

${ }^{126}$ R. Graves and A. Hodge, The long weekend, London, Faber, 1940, p. 399.

${ }^{127}$ Parliamentary Debates, Commons, 1941, 373: 66, 94, 839-842. 'Leaflet issued by the Society of Herbalists, in response to the Pharmacy and Medicines Act, 1941'. Herbal Review, 1978, 3: 22-24.

${ }^{128}$ Herbalists had been alarmed in 1916 about suggestions for a state medical service then being discussed in the general press, see NAMH minutes, 19 and 20 July 1916.

${ }^{129}$ Tom Hunter, 'Presidential address', Medical Herbalist, 1937/38, 13: 23-28.

${ }^{130} \mathrm{~S}$. Fulder and R. Monro, The status of complementary medicine in the United Kingdom, London, Threshold Foundation, 1981. 


\section{The vicissitudes of herbalism}

and turmoil. Herbalism had to meet the challenge of a greater general awareness of scientific ideas, even if understood only vaguely by the public. At the same time it had to work out its relationship to the numerous other systems of unorthodox medicine which were becoming increasingly prominent. Defining its aims and selecting its allies was often traumatic, but it seems likely that the efforts made in the 1930s and early 40 s saved herbalism from extinction and enabled it to reappear, viable, in the seond half of the century.

Conflict of tradition and initiative often caused disruption among the herbalists and fragmentation into multiple groups. An example of dissension can be traced in the Medical Herbalist. In 1929-30, it published lively and challenging articles, for example, one by C. B. Walker explaining why he was not a member of the NAMH which "actually condones, by not repudiating, the evil practices which surround the craft". ${ }^{131}$ In the next volume, W. Burns Lingard, the editor and a past-president of the NAMH, attacked the apathy of the Association and urged his readers to combine with the larger army of faithful believers in herbal medicine by joining the Medical Botany Union, under the presidency of Flora Ames. ${ }^{132}$ The NAMH council tried to restrain Lingard but he resigned the editorship and was soon expelled from membership for identifying himself with proposals for a British Institute of Organic Medicine. Culpan, another past-president, resigned over the latter issue and both he and Lingard appeared subsequently as members of the Institute of Botano-Therapy, which was founded at about this time. ${ }^{133}$

Tensions between groups of herbalists arose because of professional considerations, such as training and requirements for membership, but another major factor was their relationship to the broader field of unorthodox medicine, as discussed below. Other differences between groups may not have been based on important issues. In Lancashire, always an active centre of herbalism, there existed a Lancashire Association of Herbal Practitioners as well as the local branch of the NAMH. Relations seem to have been cordial at most times but the Lancashire Association was still a disinct organization in the 1940s. ${ }^{134}$ Shortly before the 1939 war, another organization, the British Herbalists Union was formed and, although amalgamation with the NAMH was discussed in the 1940s, the Union still exists today as a separate entity. ${ }^{135}$

A different sort of alternative to the NAMH was the Society of Herbalists founded in 1927, largely by the efforts of Mrs C. F. Leyel. ${ }^{136}$ The editor of the Medical Herbalist welcomed the Society but naturally resented Mrs Leyel's statement that

${ }^{131}$ C. B. Walker, 'Awkward questions', Medical Herbalist, 1929/30, 5: 36-38.

${ }^{132}$ Ibid., 1930/31, 6: 37-38, 53-54, 58.

${ }^{133}$ NAMH minutes, 15 January, 1 March, 29 April, 27-28 May 1931. Directory of health practitioners, Croydon, 1935. The newly formed Institute of Botano-Therapy required members to use only diplomas approved by the Institute, see Abbott, op. cit., note 44 above, pp. 107-108, 151.

${ }^{134}$ Meetings of the Lancashire Association of Herbal Practitioners were reported, for example, in Medical Herbalist, 1929/30, 5: 50. A breach with the NAMH and subsequent reconciliation are suggested in NAMH minutes, 16-19 July 1934. The Lancashire Association is mentioned as a separate entity in World Service \& Psychic Review, 1943/44, 6 (2): 17.

${ }^{135}$ Current prospectus of the General Council and Register of Consultant Herbalists, Bournemouth. NAMH minutes, 1 \& 2 May 1946.

${ }^{136}$ 'Mrs. C. F. Leyel (1880-1957)', Herbal Review, 1978, 3: 15-20. 


\section{P. S. Brown}

"We are reviving the lost art of herb doctoring". Later, he took exception to the claim by Lady Simson that they were rescuing "this wonderful study of herbs ... from the mire into which it had fallen" and the Society of Herbalists was described dismissively as a "trading organisation". ${ }^{137}$ Trading was certainly to the fore and a catalogue of Culpeper Hosue cosmetics in the 1930s announced an advisory committee which included one marchioness, four countesses, and one baroness. ${ }^{138}$ Although founded on such a different basis to the NAMH and existing in a different sphere, the Society of Herbalists probably contributed to the mainstream of herbalism by its public criticism of the old-fashioned image as well as by extending the social acceptability of herbalism.

The fragmented groups of herbalists needed allies, and through the 1930s and early 40s a bewildering number of federations and associations came into being, often only for brief periods. In earlier decades, the NAMH had considered affiliation with other groups in order to establish its teaching institution. In 1918, collaboration with the London College of Physiology was proposed: the college planned a garden of medicinal herbs with related lectures on therapeutics, and its journal carried articles on herbal therapy. ${ }^{139}$ But no progress seems to have been made, and ten years later the NAMH was considering a joint college with Lord Clifford who offered accommodation and the provision of a lecturer on light treatment. ${ }^{140} \mathrm{He}$ wrote articles for the Medical Herbalist on colour therapy and the advantages of combining it with herbalism: ${ }^{141}$ but the idea of a joint college was rejected. ${ }^{142}$ Lord Clifford's articles were among many in the Medical Herbalist which expounded other therapeutic theories, and the herbalists, though sensitive to internal deviance, appeared broadminded in giving a sympathetic hearing to other systems. The journal published papers on nature cure, osteopathy, chiropractic, curative magnetism, hydropathy, iris diagnosis, and the Bach remedies. ${ }^{143}$ And there was some practical collaboration between different systems in the Hospital for Natural Healing in Forest Gate, London. ${ }^{144}$

Legislation, either threatened or accomplished, precipitated crises in the affairs of the herbalists and drove them urgently to seek solidarity with other unorthodox practitioners. In the mid-1930s, the proposed Medicines and Surgical Appliances (Advertisement) Bill occasioned the foundation of the Natural Healers' Defence Union in the North and of the Health Practitioners' Defence Association in London, the latter being supported by the NAMH. ${ }^{145}$ Rival factions can be detected in 1937

${ }^{137}$ Medical Herbalist, 1926/27, 2: 202; 1931/32, 7: 141-144, 145-147.

${ }^{138}$ Society of Herbalists, Culpeper House catalogue, [n.d.] (Wellcome Institute Library).

${ }^{139}$ NAMH minutes, 17 \& 18 July 1918. Physiologist, 1917, 1 (NS): 47; 1918, 2 (NS): 25-27. Physiologist and Optologist, 1928, 5: 175-198.

${ }^{140}$ NAMH minutes, 7 March 1929.

${ }^{141}$ Lord Clifford, 'Colour ray treatment and herbalism', Medical Herbalist, 1928/29, 4: 132-136, 144.

${ }^{142}$ NAMH minutes, 16 July 1929.

${ }^{143}$ For these topics, numbered in order commencing with nature cure, see, for example, (1)Medical Herbalist, 1933/34, 9: 8-9, 28-29, 42-43. (2)Ibid., 1928/29, 4: 35-36. (3)Ibid., 1929/30, 5: 30-31. (4)Ibid., 1927/28, 3: 200. (5)Ibid, 1934/35, 10: 142-143. (6)Ibid., 1936/37, 12: 143-144, $232-233$. (7)Hlth Herbs med. Herb., 1938/39, 1(NS): 62-63.

${ }_{144}$ Proposals for the hospital advertised in Directory of health practitioners, op. cit., note 133 above. C. M. Goodrich, 'London's herbal hospital', Medical Herbalist, 1937/38, 13: 185-186. 


\section{The vicissitudes of herbalism}

when the NAMH declined to be involved in the Congress of Natural Healing, proposed by D. J. Gibson and others, because the Health Practitioners' Association already existed with the same aims and because they feared that the new group might come under the control of the Society of Physical Medicine, an organization the NAMH had already advised its members to avoid. ${ }^{146}$ But in the same year the NAMH supported the League of Herbal Medicine Advocates. ${ }^{147}$ In 1939, C. S. Collen-Smith founded the Healers' Association to protect common interests by unity, and by 1944, sixty herbalists had joined, forming the largest group and about eighteen per cent of the membership. ${ }^{148}$

The passing of the Pharmacy and Medicines Act (1941) followed by publication of the Beveridge Report (1942) caused high alarm. Collen-Smith formed a Federation of Practitioner Organisations, at first claiming herbalist support from the British Herbalists Union and Flora Ames's Medical Botany Union and later from the Institute of Botano-Therapy and the League of Herbal Medicine Advocates. ${ }^{149} \mathrm{He}$ was not supported by the Lancashire Association nor by the NAMH, who refused to be involved on the grounds that numerous attempts to form federations of unregistered practitioners had recently been unsuccessful. They were probably also unwilling to be associated with Collen-Smith and his journal, World Service, because of his commitment to spiritualism and the journal's content of astrology and related matter. Instead, the NAMH affiliated with the British Health Freedom Society. ${ }^{150}$ It is clear that, even under stress, the NAMH looked critically at any alliance, and it could be argued that herbalism was nearer to orthodox medicine than to some of the other forms of "natural healing". For instance, Harry Benjamin claimed that "the genuine Naturopath does not make use of herbalism in his work" and that, while herbalism might be preferred to orthodox medicine, "The line that divides drugs from herbs is sometimes very thin indeed". ${ }^{151}$

Despite the herbalists' failure to achieve political solidarity in the 1930 s and early $40 \mathrm{~s}$, herbalism as a therapeutic system established attitudes and consolidated principles at that time which prepared it for ready acceptance by a new public in the second half of the century. One element was the sharpening of its scientific approach to phytochemisty and pharmacology, as explained by F. Fletcher Hyde, who was himself active in this movement. ${ }^{152}$ Progress of this kind brings herbalism closer to regular medicine, but much of the present appeal of herbalism to the public must

\footnotetext{
${ }^{145}$ Ibid., 1934/35, 10: 35, 49-50, 54-55. This journal also made favourable mention of the Health Practitioners' League and the Health Practitioners' Union, but their relationship is not clear. See also, Health Practitioners Journal, 1935/36, 1: 3-8, 55, and ibid., 1-2, where it is suggested that the unregistered therapists should be "complementary" to orthodox medicine.

${ }^{146}$ NAMH minutes, 1 October, 5 November 1936, 4 February 1937.

${ }^{147}$ Ibid., 4 March 1937. Hlth Herbs med. Herb., 1938/39, 1 (NS): 37.

${ }^{148}$ World Service and Psychic Review, 1941, 4(1): 23 and thereafter. E. F. Bentley, 'The prevention of a medical monopoly', ibid., 1944, 6 (10): 19-20. The Healers' Association's Institute of Therapeutics offered postal tuition in botano-therapy, leading to the L.B.Th. and P.B.Th., see ibid., 1943/44. 6 (4): 20.

${ }^{149}$ Ibid., 1943/44, 6 (1): 16; 6 (2): $17 ; 6$ (4): 24.

${ }^{150}$ Hlth Herbs med. Herb., 1943/44, 6 (NS): 581-582, 588, 599-600.

${ }^{151}$ H. Benjamin, Everybody's guide to nature cure, London, Health for All Publ. Co., 1936, p. 79. This was a purist view and many naturopaths used herbs. The NAMH corresponded with the National Association of Naturopathic Herbalists of Amercia, see Hlth Herbs med, Herb., 1938/39, 1 (NS): 217.

${ }^{152} \mathrm{~F}$. Fletcher Hyde, 'The origin and practice of herbal medicine', Mims Magazine, 1978, 2: 127-136.
} 
depend less on this closeness and more on its contrasts with medicine. Emphasis on healing by the body's own resources, the avoidance of poisonous medicines, and a concern with the general way of life of the patient had all been stressed by herbalists earlier in the twentieth century, and these ideas had been reinforced by contact with other systems of "natural healing". In the second half of the century, these considerations seem even more relevant. Scientific medicine has "progressed" to a stage where most studies suggest an incidence of between ten and twenty per cent for adverse reactions to drugs given in hospital, and the general practitioner may have only about four minutes to devote to each patient. ${ }^{153}$

These trends in medicine were recognizable in the 1930s, even to some of the medical profession. An editorial in Medical World in 1936 announced that "we are beginning to encounter what may be termed 'therapeutic disorders', the direct outcome of the 'treatment' employed." Consequently, the patients were drifting away to the unorthodox practitioners, and this drift was probably "not so obvious amongst the poorer and working classes, but it is certainly only too obvious amongst the rich". ${ }^{154}$ Probably few of these drifting patients consulted herbalists, but since then, partly for reasons noted in the 1930s and partly because of an easing of economic necessity, it is likely that the herbalist's practice has changed greatly. Few of his present-day patients can be seen as the counterparts of the industrial poor who provided a large section of the herbalist's practice in the past. The striking changes in social conditions, the welfare state, and the improved economic and educational opportunities, must all have altered the type of demand for herbal therapy. Patients needing to seek out the herbalist for inexpensive treatment must have virtually disappeared, while the proportion consciously choosing herbal therapy for thoughtful, idealistic, or even experimental reasons must have increased, This, however, is speculation until objective information on the social characteristics of contemporary herbalists' patients is available. In its absence, the best that can be offered is the impression of Fulder \& Monro, based on data which they do not publish, that complementary medicine in general is used most by the "better educated sectors of society". ${ }^{155}$

\footnotetext{
${ }^{153}$ D. M. Davies, 'Epidemiology' in D. M. Davies (editor), Textbook of adverse drug reactions, Oxford University Press, 1981, pp. 3-8. G. Stimson and B. Webb, Going to the doctor, London, Routledge \& Kegan Paul, 1975, p. 60.

154 'Medicine and the public', Medical World, 1936, 45: 139-140.

${ }^{155}$ Fulder and Monro, op. cit., note 130 above, pp. 45-46.
} 